Article

\title{
Eco-Hammam: The Complexity of Accelerating the Ecological Transition of a Key Social Heritage Sector in Morocco
}

\author{
Magda Sibley*(D), Camilla Pezzica *(D) and Chris Tweed (D) \\ Welsh School of Architecture, Cardiff University, Cardiff CF10 3NB, UK; TweedAC@cardiff.ac.uk \\ * Correspondence: sibleym@cardiff.ac.uk (M.S.); pezzicac@cardiff.ac.uk (C.P.)
}

\begin{abstract}
Hammams are key providers of affordable hygiene and wellbeing services for the less wealthy in the Maghreb region. However, the UN climate change conference COP22, held in Marrakech in 2016, highlighted hammams are major contributors to air pollution, deforestation, loss of ecosystems, water overconsumption and wastage in Morocco. This paper analyses the complexity of advancing their energy transition from the viewpoint of key stakeholders engaged in two half-day virtual forums focusing on the water-energy nexus; organised as part of the AHRC funded project "Eco-Hammam: engaging key stakeholders with bespoke low-carbon technologies for lighting, heating, and water recycling to sustain a Moroccan heritage". Results reveal that the Moroccan hammam sector could benefit greatly from stakeholders' networking and collaboration to accelerate the uptake of low-carbon technologies and ecological practices. Key stakeholders' priorities and barriers (economic, policy-induced or governance related) are presented and show that the lack of coordination between governmental and non-governmental organisations is perceived as contributing to the slow pace of the hammam energy transition. Although managers seem fully aware of available energy transition technologies for their furnaces, energy and water are treated independently and disconnected in their governance. Finally, Marrakech is identified as a potential hammam sustainability hub.
\end{abstract}

Citation: Sibley, M.; Pezzica, C.

Tweed, C. Eco-Hammam: The

Complexity of Accelerating the

Ecological Transition of a Key Social

Heritage Sector in Morocco.

Sustainability 2021, 13, 9935. https://

doi.org/10.3390/su13179935

Academic Editor: Chiara Delmastro

Received: 16 August 2021

Accepted: 1 September 2021

Published: 4 September 2021

Publisher's Note: MDPI stays neutral with regard to jurisdictional claims in published maps and institutional affiliations.

Copyright: (C) 2021 by the authors. Licensee MDPI, Basel, Switzerland. This article is an open access article distributed under the terms and conditions of the Creative Commons Attribution (CC BY) license (https:/ / creativecommons.org/licenses/by/ $4.0 /)$.

Keywords: energy transition; climate design; sustainable urban development; stakeholders' engagement; Moroccan hammams; living heritage; urban renewal; governance

\section{Introduction}

Heritage hammams in the Maghreb historic cities continue to be an important living heritage in the 21st Century, as highlighted by past research on the surviving and still functioning historic public bathhouses (hammams) of the North African heritage cities of Marrakech, Algiers, Tunis, Tripoli and Cairo [1,2]. Morocco is where the largest number of functioning heritage hammams have been surveyed and where new hammams are part of the cluster of key urban facilities introduced in every new residential neighbourhoods in accordance with local planning regulations.

Hammams contribute to social sustainability by providing a much-needed affordable facility for the hygiene and wellbeing of the economically disadvantaged population in the area [3]. Additionally, the multi-generation reproduction of the collective bathing performance, beyond the bathing and purification ritual, means that the spatial practice of the hammam can contribute to build and strengthen social and cultural capital and continue supporting the physical and mental health of women in post-traditional Morocco [3,4]. Nonetheless, hammams face an increasing number of challenges threatening their continued viability as a public service, which might lead to their closure and disappearance after many centuries. Amongst these, there are the increased costs of fuel (wood or diesel) and water [5].

Further developments that have emerged from the UN climate change conference COP22, held in Marrakech in 2016, have questioned the environmental sustainability of 
Moroccan hammams since these were presented as important contributors to natural assets' depletion and anthropogenic climate change in the region.

It was estimated at COP22 that Morocco has at least 12,000 hammams, operating with wood burning vernacular furnaces. Given that each hammam consumes, on average, 1.5 tonnes of wood and between 60 to 120 cubic meter of water per day, the accumulated environmental impact of more than 12,000 hammams can be significant in terms of deforestation, environmental degradation, loss of ecosystems, air pollution, $\mathrm{CO}_{2}$ emissions and high water consumption with no recycling strategies.

Several technical solutions have thus been developed to reduce hammams' environmental impact, ranging from bespoke improved furnaces, locally produced by the Moroccan Agency of Energy Efficiency (AMEE), to high-efficiency, minimumpollution boilers using local bio-mass products (such as residues from olive or Argan oil presses), to more sophisticated hybrid systems combining water solar heaters (from an innovative solar ring providing off-grid solar-powered LED lighting for the hammam bathing spaces) and high efficiency biomass boilers [6]. Additionally, various uncoordinated attempts were made by both National and International Renewable Energy and Energy Efficiency organisations to facilitate energy transitions in the hammam sector. These organisations include the AMEE [7], the German Technical Cooperation (GTZ) [8] and the French Development Agency (AFD) [9] with GERES [10]. However, it is estimated that, to date, only 67 out of the 12,000 hammams have made progress in fuel-switching, indicating very slow progress despite national and international efforts to address the problem.

As well as reducing the environmental impact of the hammam furnaces and chimneys, two other important areas need urgent attention: (i) improving hammam workers' and users' health and safety and well-being in the hammam spaces; and (ii) reducing water consumption as well as implementing water recycling strategies where possible. These issues have a broad societal impact as each hammam receives an average of one hundred clients daily and the same hammam operates different daily time shifts for men and women, employing teams of female and male staff at different times of the day as well as staff working in the furnace area. Therefore, accelerating the whole ecological transition of hammams is necessary to have a significant accumulated impact on the health and well-being of Moroccans who continue to use these public services on a weekly basis. Some specific issues are skin diseases from water contamination, stress due to reduced access to daylighting and natural ventilation, and respiratory problems due to air pollution from fossil fuels [11], whose combustion releases hazardous chemicals reaching high concentrations in the furnace room, in addition to several hundreds of kilos of $\mathrm{CO}_{2}$ each day, contributing to environmental degradation.

A wide range of technical rehabilitation strategies for hammams are known and knowledge of solutions is already available [12]. For instance, the health and wellbeing of hammams' users and staff can be supported by introducing as much natural daylight and ventilation as possible $[13,14]$, reducing the risk of fire, disease transmission and accidents. Innovative retrofitting strategies for daylight in hammam buildings were developed by Sibley [15], based on vernacular features connected to the careful environmental engineering of hammam buildings in the local architectural tradition. These address the lack of daylight in contemporary hammam bathing spaces, as the original vernacular daylighting system has been made redundant in most of the heritage hammams of North Africa, by exploiting renewable solar energy resources for lighting. Furthermore, different authors indicate that water can be saved by developing responsible water consumption with efficient water drainage and recycling systems [16]. Although its buy-in is low, meaning these issues remain widely unaddressed to date, previous research [3] stresses that the hammam institution is well positioned to successfully negotiate the social, architectural and cultural transformations currently ongoing in Morocco, and continue its service in supporting communities' health and wellbeing.

This paper presents preliminary results of the Eco-hammam AHRC funded research project (Section 3), which aims to facilitate the acceleration of the energy transition process 
in Moroccan hammams (both long established and newly built ones) and the reduction of their ecological footprint by focusing on aspects of resource efficiency, use of renewables, fuel switching and behavioural change. This research is based on the understanding that accelerating the ecological transition of Moroccan hammams requires adopting a holistic approach that involves the participation of all key stakeholders about cross-scale environmental, social-economic and political drivers, and the co-production of future strategies.

The research advocates the need to abandon unconnected silo paradigms focused on resources' security and to adopt a systemic approach to the study of dependencies between Water-Energy-Food (WEF) systems [17] in the hammam sector. Social and cultural aspects are a key part of this investigation, which seeks to establish a link between top-down and bottom-up decision-making processes. As explained in Section 2, this fills a gap in existing scientific literature about the energy transition in hammams and in Morocco.

Within this framework, the paper presents the results of the first phase of the research, which examines the barriers to the uptake of low carbon technologies for water heating while considering, among other issues, the impact of excessive water consumption and wastage on efficient energy use.

\section{The Energy Transition in Morocco: Technology, People, and Nature}

The impact of human activities on natural systems is increasingly recognised as an important risk factor for sustainable development [18]. Morocco has put the transition to a green economy at the centre of its strategic development due to the threats posed by climate change to development, economic stagnation, high energy importation, and water scarcity [19]. However, micro-financing tools for small-scale renewable energy projects are needed to enable the vulnerable local population to adapt [19]. Preferences in the adoption of low-carbon electricity generation technologies are led by an economic rationale, and therefore future energy policies should tackle financial barriers to investments in the area [20].

These studies highlight technical and economic factors, with implications for energy transition in the hammam sector. Nonetheless, they fail to address the role of social and/or cultural elements in making the transition to low-carbon technologies effective, and in guiding small businesses towards informed choices about the adoption of low-carbon technologies or support them in doing so. Furthermore, in Morocco, the centralised and technocratic approach to decision-making hinders multi-stakeholders' participatory design of energy transition [20]. This goes in the opposite direction of the Dasgupta report [21], which advocates the integration of knowledge and views from actors across the global, national, regional and local levels to enable collaborative, participatory and coordinated action for sustainably managing ecosystems.

Science and Technology Studies (STS) [22] and sociotechnical [23] researchers highlight the importance of understanding the relationship between daily life and technologies, as well as the social-cultural and political implications of technology on (spatial) development processes in a given territory. Scholarship in this area engages in qualitative research on the work of technical experts (e.g., engineers, designers, policymakers) but also considers the influence exerted by local users and other 'non-technical' actors on technology development and management. In fact, according to this view, technological development is a contingent process as technology is spatially and culturally embedded in a context, which makes the introduction of new off-the-shelf solutions potentially contentious.

Shove [24] and others [25-27] emphasise the importance of adopting a sociotechnical approach to energy and comfort in the built environment to effect reliable change in energy consumption. The treatment of energy in buildings follows an increasingly inclusive path beginning with the introduction of technical solutions to providing heating and cooling, as documented by Banham [28], then embracing human needs and desires through physiological comfort studies [29] before widening to include social and cultural aspects, as noted above. While many still follow a mainly technical approach to energy in buildings, the need to bring end users on board when seeking change to energy and environmental practices 
is now widely recognised. It has progressed beyond the simplistic 'behaviour change' expected of end users to embrace more participative and collaborative approaches [30,31].

Although related discourses are rooted in environmental issues such as natural resources consumption, Sustainable Development is increasingly seen as a social project, which demands new governance and decision-making practices [32]. For instance, Meppem [33] argues that genuine stakeholder collaboration based on learning - what the author calls "discursive community" - is necessary to develop more effective sustainable development processes, which holistically take into account economic, socio-cultural, and environmental aspects. Botai et al. [34] advance that, to effectively support Sustainable Development Goals (SDGs), operationalising the Water-Energy-Food nexus research in Africa is key and that this requires skills training, and the co-development of tools, expertise and institutional capacity by scholars, practitioners and society.

The strategic objective of the Eco-hammam project supports the implementation of the 2030 agenda for Sustainable Development [35]. Specifically, the project seeks to facilitate democratic stakeholders' engagement and social learning [36] to bring light on the role of the hammam sector in achieving the following SDGs: Good health and wellbeing (SDG3); Clean water and sanitation (SDG6); Affordable and clean energy (SDG7); Sustainable cities and communities (SDG11); Climate action (SDG13). This paper presents results from the first part of this project, whose context and full research plan are outlined in the next section.

\section{The Eco-Hammam Project}

Different aspects of the hammams in Morocco fall under different Ministries, such as The Ministry of Tourism, Air Transport, Craft and Social Economy; The Ministry of Religious Endowments and Islamic Affairs, and their operation is also of concern to The Ministry of Agriculture, Fisheries, Rural Development, Water and Forest and the Ministry of Energy, Mines and Environment. The diversity of these actors, and of those at lower levels of governance with a stake in the hammams' energy transition process, means they can have different priorities. Conflicts can then be exacerbated by the lack of coordination and collaboration among decision-makers, including the Ministries, political groups and national and international NGOs [37].

Adopting a transdisciplinary research approach and participatory and deliberative research methods can help in coordinating such diverse groups of actors with potentially different goals and interests [17]. Therefore, the Eco-hammam project aims to bring together all stakeholders operating across multiple governance levels, via their creative engagement and networking, with the objective to facilitate the acceleration of the ecological transition of hammams in a self-sustained way.

The creative engagement of stakeholders demands the involvement of multidisciplinary and multi-sectoral teams of facilitators working with the participants of regional events to co-produce ecological transition scenarios. These are based on real case study hammams selected in different Moroccan cities and regions, which should continue to act as a regional anchor that will self-sustain future follow-up activities and initiatives for best local practices in ecological transitions.

Several project partners have been involved in the delivery of the knowledge generation and transfer activities and contribute to the achievement of the common goal of the Eco-hammam project. These include National Governmental and Non-Governmental organisations, one International Development organisation, a local biomass cooperative and a local producer of bespoke biomass boilers in addition to a local university, namely:

- The Moroccan Agency of Energy Efficiency AMEE (Governmental organisation within the Ministry of Energy, Mines and Environment).

- The Moroccan Cooperative Listijmam WaRaha for ecological hammams. This is a private cooperative with an active role in the Hammam Managers National Federation (F.N.A.P.G.H.T.D.M.) and with strong links to Ribat El Feth Association, one of the most established NGOs in Morocco working on Sustainable Development projects. 
- ICT Environnement. This is a local industry partner producing bespoke low pollution biomass boilers to heat both water and hypocaust of the traditional hammams.

- Architecture \& Development (A\&D), an International French NGO, which implements development projects in remote and deprived rural areas.

- The Moroccan National Federation of hammam owners and managers (F.N.A.P.G.H.T.D.M.).

- A group of expert hammam professionals. This includes an engineer and owner of four hammams, who championed the energy transition using hybrid solar water heaters and bio-mass high efficiency furnace, and an internationally recognised French/Moroccan architect with experience in the rehabilitation of historic hammams.

- The Ecole Nationale d'Architecture de Marrakech (ENAM), with a multidisciplinary team of staff working on the protection and revitalisation of Moroccan heritage in collaboration with ICOMOS and UNESCO.

- Musée Mohammed VI. This is the museum for the civilisation of water in Morocco and is linked to the Ministry of Religious Endowments and Religious Affairs.

The project plan encompasses five separate actions, which collectively seek to facilitate the development of an integrated approach towards accelerating ecological practices through the co-production of holistic Eco-hammam strategies and the acceleration of their implementation:

1. Construction of a database of key regional stakeholders in collaboration with the local project partners (such databases were missing and therefore communication between different stakeholders was non-existent).

2. Organisation of a series of thematic virtual forum events for accelerating the ecological transitions processes in Moroccan hammams through the establishment of regional key stakeholders' networks, so as to creatively engage them to communicate and co-produce integrated strategies for multi-sectorial coordinated actions. The activities were video-recorded for enabling the analysis and identification of emerging priorities and barriers of stakeholders in relation to the hammams' ecological transition.

3. Creation of open communication channels through social media and web platforms [38] to facilitate communication and exchanges between previously unconnected stakeholders (both pre- and post-forum events) and across regions.

4. Co-monitoring of the established Eco-hammam project's social media and web platforms for feedback on events, discussions and follow-on initiatives. This enables also measuring the impact of each engagement event.

5. Co-production of a toolkit for hammams' energy and ecological transition for facilitating the implementation of Eco-hammam practices by hammam operators and the local public. Toolkit proposals (e.g., serious games, animations and videos, a rating system for the acquisition of the label of 'ecological hammam') are being fine-tuned, based on the results of the different virtual engagement events, including the thematic monthly forums and workshops and focus group discussions organised with a view to raising the awareness of different stakeholders about the challenges of hammams' ecological transition and to build consensus for a shared course of actions.

This paper presents results from the completion of the first three steps of the project, described earlier in Section 3. It illustrates the mapping of the various stakeholders of the hammam sector and their potential impact on ecological transition based on the WaterEnergy nexus as investigated through their engagement with monthly Eco-hammam thematic forums, conducted between the summer 2020 and the spring 2021.

The project is currently analysing the multiple stakeholders' presentations and discussions to develop a clear understanding of which actors are involved in the ecological transition process, their drivers and challenges and the perceptions of hammam managers of energy transitions opportunities. By doing so, the project establishes the state of the art of energy transition in Moroccan hammams at local and national levels and provides a new understanding of the challenges faced by Moroccan hammams to ignite inter- and cross-regional lever projects. 


\section{Materials and Methods}

In the Moroccan hammam context, energy transition is understood as a set of actions that are aimed at reducing the total energy consumption through a well-insulated energy efficient building, a rehabilitated hammam furnace for heating the hammam water and building with an energy-efficient hammam boiler, a shift in the boiler's fuel from highly polluting fuels to less polluting ones that are from renewable sources such as biomass and solar energy, a responsible consumption of hot water and the ability to recuperate heat from used water.

Ecological transitions in hammams include, in addition to their energy transition, behavioural aspects such as a responsible consumption of cold and hot water by both building users and workers, design decision-making aspects (for new hammams or the retrofitting of existing ones) for increased indoor natural lighting and appropriate ventilation while maintaining building energy efficiency, integrated water recycling strategies and management decisions for improved building indoor conditions that enhance occupants ${ }^{\prime}$ wellbeing and safety.

The complexity of accelerating the hammams' energy transition is investigated in this paper through the analysis of the multiple narratives and views of those involved with the hammam sector, in a manner that is methodologically sound and at the same time sufficiently open [23].

Six virtual forums, each lasting half a day, were conducted between July 2020 and March 2021, through which a wealth of qualitative and quantitative data about different themes connected to the hammams' ecological transition was gathered. Each forum brought together different key stakeholders to present and discuss a theme related to energy and ecological transitions in heritage and contemporary hammams in Morocco.

These forums were recorded and made available through the project 's website and its YouTube platform. Stakeholders were either invited and/or self-enrolled to the forums through a snowball process, facilitated by the increased visibility of the project through its website and social media platforms such as Facebook and YouTube. The forums have been recorded (with the approval of the participants), then transcribed and analysed to identify emerging themes and positions in relation to hammams' energy and ecological transitions of the various participating stakeholders.

This paper presents the results of the qualitative analysis of two of these forums, based on stakeholders' transcribed discussions and views around two interdependent themes: water and energy. The forum discussions were prompted by research data and scientific literature presented by experts and by their feedback, to enrich and triangulate results.

\subsection{Stakeholders' Identification and Mapping}

The recruitment of hammam stakeholders started with a list established by the principal investigator in previous research and field work on hammams in Morocco [39]. This list included Governmental and Non-Governmental National and International Organisations as well as hammam managers and was used to recruit other stakeholders through snowball sampling and by asking a set of questions [40] to experts and project partners with an in-depth knowledge of the hammam sector. The initial database was then expanded as the project progressed with data provided by two project's partners: the Listijmam WaRaha Cooperative and the Moroccan Agency for Energy Efficiency (AMEE), who had organised a hammam stakeholders' conference in 2017. Additional data were retrieved during the delivery of the project from the digital self-enrolment forms that are open to all, to enable participants to join the online monthly forums of the Eco-hammam project. Data collected online and from the project's partners includes stakeholders' contacts, affiliation, profession and relationship to the hammam sector. Additional snowball sampling was used to triangulate results [41], by asking all stakeholders engaged in the online forums about their views on whom they consider as Moroccan hammam stakeholders and by encouraging them to circulate the forums' invitation to those who they thought would have an interest in attending. To this end, the National Federation of hammam managers in Morocco, as 
one of the key stakeholders representing hammam managers across the whole country, has been actively engaged from the beginning of the Eco-hammam project.

Having established a list of all stakeholders engaged with the project after the completion of all the six Eco-hammam forums, a mapping exercise was conducted using a power/interest matrix [42], which is a useful tool for enabling constructive and equitable values-based stakeholder interaction when assessing sustainability [32]. This mapping method considers stakeholders' mutual relationships by grouping them according to similar levels of power (direct and indirect) and interest (as expressed by stakeholders and perceived by the research team). This helps planning stakeholders' engagement activities with hammams' ecological transition projects [42].

\subsection{Online Engagement Forums: Approach and Analysis}

Hammam stakeholders' engagement and network facilitation events were initially planned as a set of three-day regional public engagement seminars and network facilitation workshops, involving more than a hundred key regional stakeholders in each of the world heritage cities of Rabat (the political capital of Morocco), Fez and Marrakech. The plan to hold them in Morocco in 2020-2021 had to be adjusted due to the COVID-19 outbreak.

Due to practical considerations linked to the impossibility of organising large group workshops, the project shifted to the organisation of monthly virtual engagement events, conducted between November 2020 and March 2021, following a two-day project kick-off opening event in July 2020.

The forums were organised in an innovative format inspired by the method of online deliberative discussion focus groups [43]. The method is based on identifying ways to educate and inform participants about the topic of interest prior to the focus group discussion in order to promote more quality data from informed opinions [43].

Focus groups help the understanding of attitudes and opinions, which are socially formed, and are conducted in a social environment in which they can be articulated [44]. These are particularly useful when power differences are present among the focus group participants [45] which is the case in the Eco-hammam project. However, the in-depth engagement with a group of stakeholders presents some limitations in terms of results' generalisation as the sample of participants could be considered as non-representative.

Traditional focus groups normally study the interaction of 6-8 people and last 60-90 $\mathrm{min}$ [46]. By contrast, the number of participants engaged in the Eco-hammam online deliberative discussion focus groups was significantly higher, from a minimum of 29 to a maximum of 70 stakeholders, and the duration of each event was approximately $240 \mathrm{~min}$. The number and type of participants was not selected in advance as open invitations were circulated among all the contacts before each virtual forum event. Additionally, the role of the researcher was not limited to the moderation and facilitation of the discussion but involved the active provision of information to participants together with experts, who were available for questioning.

The latter is a typical feature of deliberative research (a particular participatory research method that aims to achieve informed judgements through public reasoning) [47]. Participants were informed about a topic prior to the focus group discussions to obtain better quality data from informed opinions, which helps to overcome issues with the uncertain nature of data produced during traditional focus groups and was considered unproblematic in the context of this study. Similarly to deliberative studies, this research considered that participants can positively transform their beliefs and values, as a result of their involvement in the discussions [40]. In other words, social learning was exploited to support a deliberative dialogue between stakeholders, based on respect for different forms of knowledge and understanding, in order to inform decision-making processes [36].

To this end, discussions prompted by thematic presentations were left intentionally unstructured as participants were allowed and encouraged to interact with each other using the virtual platform of Google meet and moderated by the project team. All participants clearly preferred verbal communication to using written comments in the platform's chat, 
which allowed the observation of all interactions by the large number of participants via their screens. This would not have been possible to achieve if the interaction format was based on a physical meeting, as all participants cannot be seen simultaneously observed as they build on each other's comments and react to opinions in a quasi-conversational manner accessible to all.

With the permission of the participants, the online forums (held mainly in French and Arabic) were recorded and transcribed in full to avoid data loss, while retaining the context in the visual recordings to support interpretation in their subsequent systematic inductive analysis [48]. This paper focuses on the analysis of two of the five engagement events: "Eco-hammam and the water", held in November 2020 with 70 participants; and "Ecological transitions and sustainable development: problems and expectations of hammam owners and managers", held in December 2020 with 43 participants. Both events lasted approximately three and a half hours, each alternating focus on thematic presentations and stakeholders discussions.

The transcripts of these focus groups were translated into English to support the examination of their content via constant comparison analysis [49]. This analysis method encompasses three stages: (i) splitting of data in small chunks (open coding); (ii) grouping of codes in categories (axial coding); (iii) theme identification (selective coding). The themes extracted are then illustrated using anonymous quotations from focus group participants, specifying the category of the stakeholder quoted in the text.

Analysing the data from the two engagement forums in parallel via a constant comparison analysis enables assessing if themes present in one focus group discussion also emerged in the other group, which supports the data and/or theoretical saturation assessment [48]. Furthermore, increasing the diversity and quantity of empirical information (as presented in thematic clusters) contributes to substantiating the reliability of the analysis results [50].

In organisational and management studies, qualitative research is growing in importance [50]. This paper uses qualitative research to bring to light the complex relationships between technical, environmental, social and economic dimensions when addressing energy and ecological transitions in Moroccan public bathhouses. This is achieved by mapping and identifying patterns in stakeholders' discourse during group discussions triggered by thematic presentations in the two Eco-hammam project engagement events around water and energy.

This paper focuses on the analysis of stakeholders' presentations and discussions as recorded in the two forums. Through inductive reasoning, this approach enables advancing the understanding of the obstacles that prevent accelerating the energy transition of Moroccan hammams and opening new research avenues.

\subsection{Social Media, Web Engagement and Monitoring}

Organising online events instead of face-to-face meetings offers stakeholders the opportunity to overcome travel-related barriers, but limits the engagement of, e.g., computerilliterate people and those without access to a personal computer. As a result, certain groups of stakeholders such as the hammam users and workers ended up being underrepresented in the deliberative focus groups discussions, while those with access to a computer were prevalent. The events were, however, broadcasted live on a partner's organisation Facebook page [51] so that stakeholders could be aware of the ongoing discussions and post questions and/or comments by using a smartphone.

The conduct of the online engagement events during the COVID-19 lockdown meant that new ways had to be found to keep stakeholders engaged with the project. The introduction of monthly forums and engagement events has attracted a diversified group of stakeholders from sectors that are directly or indirectly related to public bathing facilities in Morocco. Stakeholders' confinement to their homes has meant that the participation in the online events has been high due to the lockdown situation, which included the hammams for many months. 
To engage people during the crisis, the project needed an accessible and reliable online presence, which required providing clear instructions for using relevant communication software and making available multiple means/routes to the stakeholders for contacting the project team. Furthermore, to break down the distance created by remote communications, key stakeholders and local partners were frequently engaged via more direct routes (e.g., phone calls and WhatsApp messages).

A dedicated website focused on the key themes of the hammams' ecological transition (accessible at [38] and translated in three languages) was set up at the beginning of the project and was regularly updated with information collected in the virtual forums and technical resources provided by the speakers and experts. The website enabled stakeholders to freely register in the online forum events by filling a digital enrolment form and the information collected contributed to updating the database and conducting a hammam stakeholders' analysis (Section 4.1).

In addition to this, different social media platforms, namely Facebook, YouTube and LinkedIn, were used to make the recordings available to different audiences and this also helped in monitoring the number of viewers. This allowed the project to increase public interaction with the events well after their completion. As an example, the number of visualisations in [51] of the two online events analysed in this paper reached 675 (forum on water) and 528 views (forum on energy) on the 26th of July 2021.

As such, social media data provide useful indicators to measure levels of engagement and impact of the online Eco-hammam forum events.

\section{Results}

Figure 1 presents the analysis of the hammam stakeholders who are directly or indirectly involved in the Moroccan hammams' sector and its ecological transition.

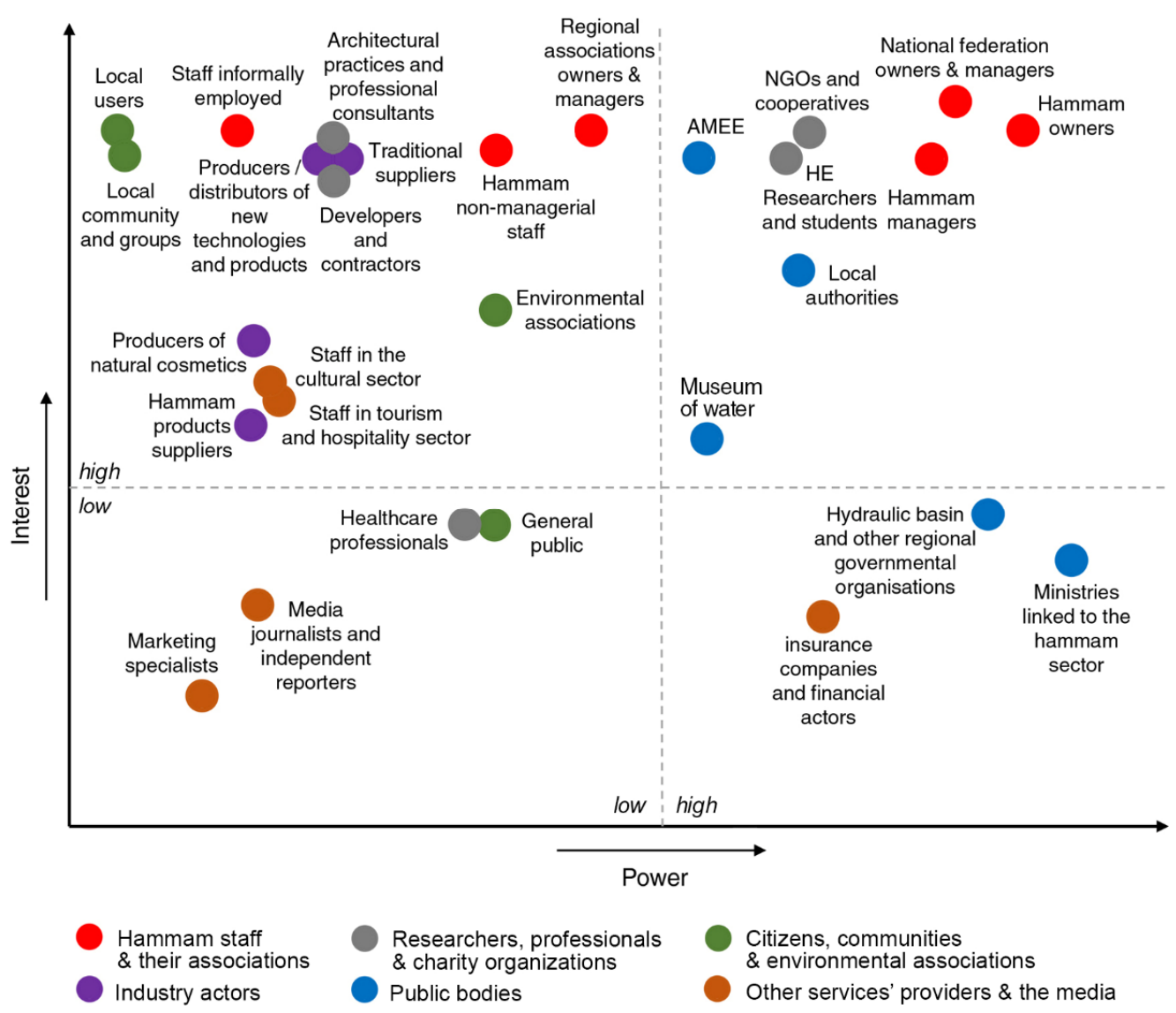

Figure 1. Interest/power map of hammams' stakeholders (different colours in the map correspond to macro-clusters of stakeholders). 
The matrix grid helps distinguish stakeholders based on their levels of interest in the hammams' ecological transition programme and power of delivering it. Although relationships, the context, and levels of interest and power are subject to change, by highlighting the importance of actors and interest groups in the transition process at the beginning of the project, hypotheses can be generated for mobilising the support of stakeholders from a prospective viewpoint and drafting the engagement and communication plan [52].

The first group consists of high interest and high power stakeholders (Figure 1, top right quadrant). These are key players in the delivery and implementation of strategies for the acceleration of energy and ecological transitions in the hammam sector. They include actors who are directly connected to the hammam institution such as hammam owners, hammam managers (both male and female as hammams are run by men and women at different times of the day), the National Federation of Hammam managers (F.N.A.P.G.H.T.D.M.), as well as research institutions with their academic members (researching on issues related to the hammam such as water, energy and public health), national and international NGOs and cooperatives with direct links to one or more aspects of hammam operation, and local authorities who have already taken action and/or may support others implementing solutions and/or apply for funding or are in a position to make operative decisions.

In this quadrant, there are those who have been involved in the improvements of hammam furnaces post COP22 and the introduction of high efficiency solutions such as, for instance, biomass boilers. Local authorities were added to this quadrant because of their interest and influence in reducing the environmental impact of hammams, to protect the surrounding urban areas from smoke from hammams' furnace and other nuisances, such as water and air pollution, and safeguard public health. The museum of water of Marrakech (Musée Mohammed VI) was added to this category of stakeholders, due to its commitment to raising the awareness of the public of sustainable water usage in Moroccan hammams. The Moroccan Agency for Energy Efficiency (AMEE) is an important public stakeholder at a national level, due to its long-term efforts and active engagement in developing and testing new technical solutions for heating water in hammams but has limited power to influence policymaking and political decisions.

The second group consists of the high power and low interest stakeholders (Figure 1, bottom right quadrant), in which fall regional public authorities such as the hydraulic basin and governmental organisations that are institutionally linked to the hammam sector such as the Ministry of Religious Endowments and Islamic Affairs (which is responsible for heritage hammams), the Ministry of Energy, Mines and Sustainable Development, the Ministry of Crafts and Social Economy, the Ministries of the Interior, of Finances, of Commerce and Industry, and of Equipment. Instead of simply keeping them informed and satisfied, a decision was made to engage them and produce evidence to support demands for better policies enabling the transition of hammams towards more sustainable forms of energy production/use and water consumption. Insurance companies and financial actors fall under the same group and need to be considered to facilitate the economic viability of hammams' transition projects.

The third group consists of high interest and low power stakeholders (Figure 1, top left quadrant). These comprehend the regional associations of hammam owners and managers and staff formally or informally employed by the sector. Formally employed staff include the personnel involved in the operation of traditional hammam furnaces for heating water and hammam spaces, while informally employed people are those delivering body scrubbing and massages and other actors offering personal services within the hammam spaces. Many stakeholders fall in this quadrant, such as entrepreneurs in the construction industry, developers, architectural practices with established experience in designing and or rehabilitating hammam buildings and expert professionals, including sustainable development and workers' safety consultants, auditors, and professionals affiliated with specialised public bodies (e.g., the génie civil). In this quadrant, there are also international and local suppliers and distributors of green technologies, ranging from solar energy technologies 
for hammams such as solar water heaters, solar-powered water pumps, solar lighting, improved chimneys with minimum air pollution, heat exchangers, water saving technologies, water drainage and recycling technologies, ecological cleaning products, hammam natural daylight and ventilation solutions, and biomass boilers. Other stakeholders in this group are producers and suppliers of other products used in the hammams (e.g., natural soap and cosmetics), travel and event planning agencies, workers in the hospitality sector, representatives of cultural associations and heritage conservation bodies (e.g., UNESCO) and environmental associations. Local users (of all ages and genders) for which hammams represent an essential hygienic service and local communities affected by the hammams fall in this group too. These stakeholders were engaged frequently using clear communication channels, while offering them the opportunity to express their concerns and contribute to the debate about implementing transition solutions in hammams.

The fourth group consists of the low interest and low power stakeholders (Figure 1, bottom left quadrant), which are those who are weakly connected to the hammam sector and yet their engagement has a high potential to increase public awareness. It includes healthcare professionals (e.g., general practitioners, dermatologists, epidemiologists), marketing specialists, journalists, reporters and other media agents, as well as members of the general public who are not necessarily aware of matters related to hammams and their operation but could contribute to increase the visibility of hammams and their problems in the national panorama.

The stakeholders mapped in Figure 1 belong to the following six functional clusters: hammam staff and their associations; public bodies; industry actors; researchers, professionals and charity organizations; citizens, communities and environmental associations; and other services' providers and the media.

Figure 2 shows the relative representation of each of these functional clusters in the Eco-hammam project stakeholders' database, which contains a total of 220 contacts. This illustrates the average composition of stakeholders' groups, which were directly invited and/or formally enrolled in one or more of the Eco-hammam online forum events to participate in the discussions of the deliberative focus groups.
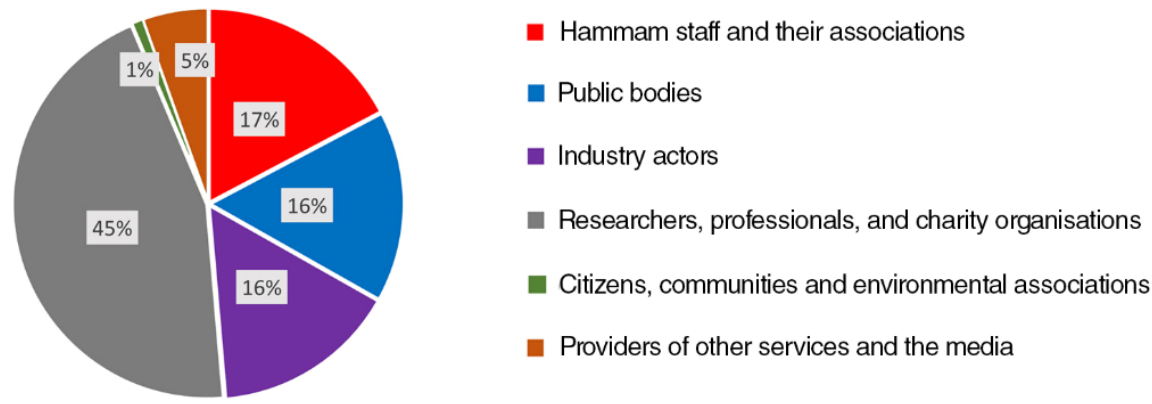

Figure 2. Types of stakeholders in the Eco-hammam's database with a total of 220 contacts.

It is clear from the pie chart in Figure 2 that the largest number of stakeholders engaged in the project falls within the "Researchers, professionals, and charity organisations" cluster, followed by the "Hammam staff and their associations" group (although within this cluster hammam owners and managers were prevalent). "Public bodies" and "Industry actors" together represent a third of the total.

As initially expected, despite leaving invitations open to all those interested, some stakeholders, among whom hammam bathers and local communities who were reached mainly via social media, did not fully participate in the virtual forums and were underrepresented in the live discussions among stakeholders during the online forums, possibly due to difficulties in getting access to the digital platform as well as to the hammams themselves, which have remained closed for many months under the COVID-19 restrictions. However, it is part of the goals of the Eco-hammam toolkit to find ways to raise the 
awareness of hammam users and engage them through more inclusive platforms, which will be easier, and possibly more effective, when COVID-19 travel restrictions are lifted.

The different levels of engagement of actors and organisations identified in Figure 1 in the Eco-hammam forums (Figure 2) confirmed the initial hypothesis that stakeholders tend to operate in a fragmented and disconnected fashion with little or no communication and/or coordination between them despite the complementary nature of their activities and objectives. Throughout the discussions, it also became clear that the forums have brought some of these stakeholders together for the time and initiated connections that would have been hard to achieve otherwise.

\subsection{Online Forum Events}

Although adaptations had to be made to the forum delivery mode due to the limiting conditions of the COVID-19 pandemic, holding regular online events resulted in the engagement of more stakeholders than initially anticipated. In total, six Eco-hammam virtual forums have been designed and delivered to bring together, for the first time, diverse hammam stakeholders from different regions of Morocco, and act as catalysts for self-sustaining coordinated national and regional processes.

Stakeholders have been engaged creatively to coproduce practical strategies and establish self-sustaining collaboration networks that will facilitate energy transitions and accelerate the adoption of ecological practices in Moroccan hammams. Each forum focused on different aspects of the hammams' ecological transition, covering the key issues of responsible energy and water production and consumption, and improved indoor conditions for hammam workers and users' health, safety and well-being (Figure 3).

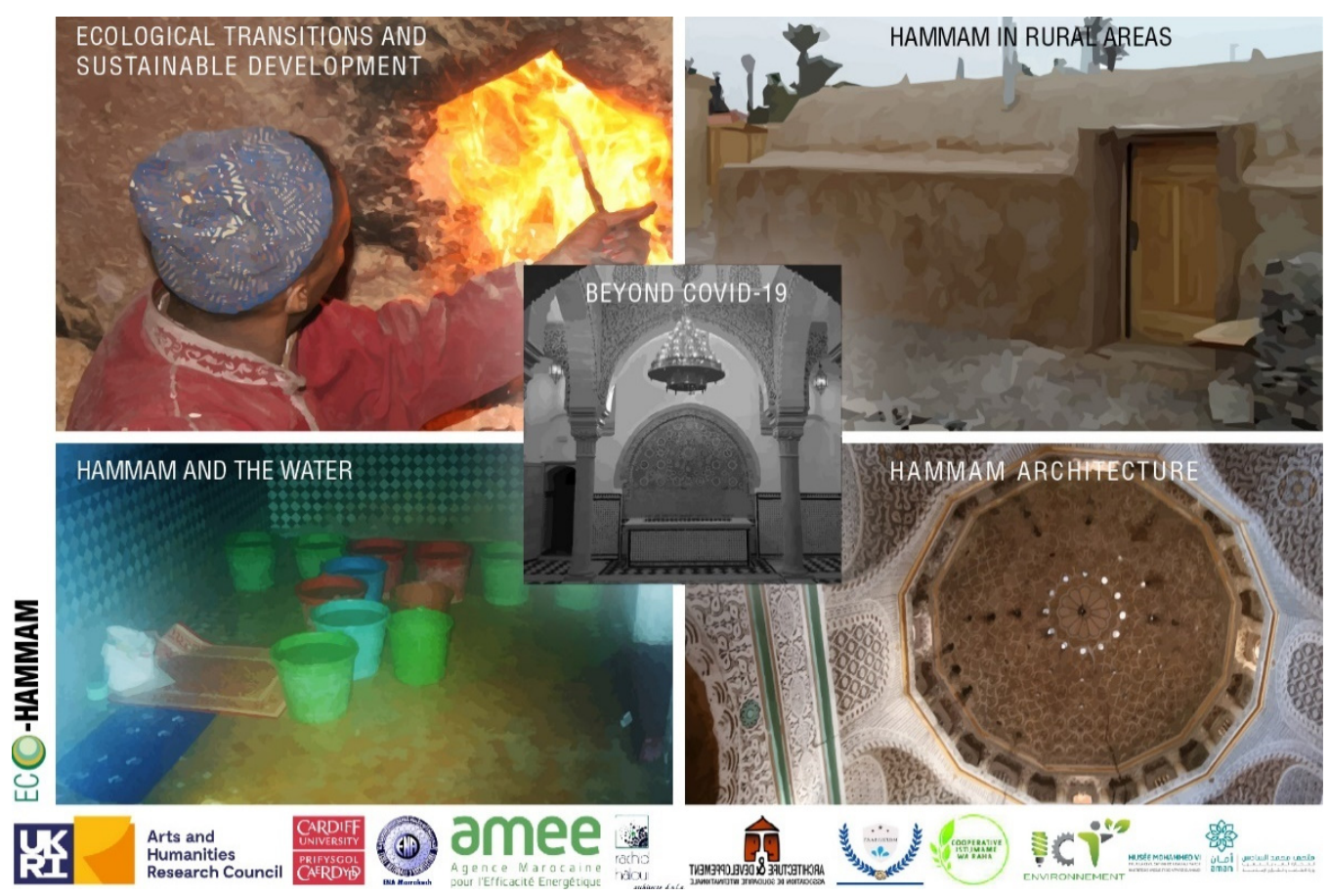

Figure 3. Sample of posters from Eco-hammam virtual forums.

To respond to pressing concerns of the stakeholders, the opening forum (titled "Ecohammam: sustainable economy and post COVID-19 transitions scenarios") was organised as a two-day event in which these key themes were jointly discussed within the framework of the ongoing COVID-19 crisis, which continues to have a major impact on the hammam sector brough about by the national closure of hammams for several consecutive months.

The interest of the public around this topic is demonstrated by its prominence in terms of number of attendees (112) and social media visualisations of the recordings (>1000), 
compared to those of the other engagement events. Figure 4 shows the relative percentage of attendees in each online forum event over the number of participants in all sessions, which reached a total of 331 stakeholders (and over 3000 views on social media).

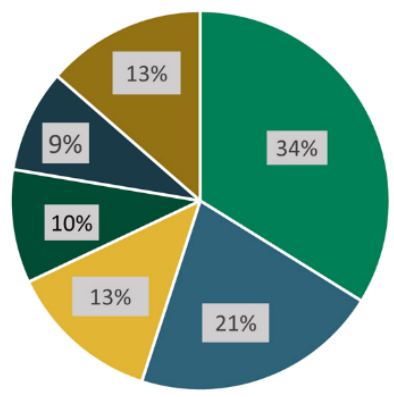

- Sustainable economy and post Covid-19 transitions scenarios

- Hammam and the water

Ecological transition and sustainable development

- Architecture and heritage hammams

- Architecture and interior atmosphere

- Rural hammams

Figure 4. Pie-chart with percentages of numbers of participants in each of the six virtual Eco-hammam forums in which a total of 331 stakeholders were directly engaged.

The pandemic has slowed down and reversed years of progress in ensuring healthy lives and well-being (SDG3) and in promoting decent work and economic growth for all (SDG8) [53]. The crisis has caused a widespread loss of jobs [54], hitting the hammams sector hard as most of the workers are engaged in informal employment and most of the jobs do not adapt to work from home. While the issue of protecting workers has recently started to be addressed in Morocco with the introduction of a new law in April 2021 that ensures generalisation of social protection to all citizens, a national strategy to promote the energy transition of hammams is absent, to date.

In 2020, the United Nations launched calls for a better and greener recovery from COVID-19 [55], which appears particularly critical for the sustainable development of Middle East/North Africa (MENA) nations due to the hazards posed by extreme temperatures and air pollution in the region [56]. Several scholars suggest the COVID-19 pandemic represents a strategic opportunity to accelerate the global transition to more sustainable energy systems through recovery funds, but note that governments need to put in place suitable economic measures (e.g., fiscal easing) to reduce initial investment costs [54,57].

The importance of financial aspects was also pointed out by different participants during the opening event, who highlighted the risks associated with the economic stress imposed by COVID-19-related restrictions on the hammam sector. Concerns were raised about the sector being "neglected, failing to attract the attention of the authorities concerned, despite its social, economic, health and cultural importance".

The following section presents the results of the analysis of transcribed stakeholders' discussions in the two engagement forums, focusing on energy and water in the context of the ecological transitions of Moroccan Hammams.

\subsection{The Water-Energy Binomial as Discussed by Participant Stakeholders in the Water and Energy Forums}

As previously stated, hammams are social and cultural institutions in Morocco, with strong links to religion, history and local costumes, and supporting the livelihood, health and wellbeing of local people and communities. The role of the hammams as an important social sector supporting the wellbeing and the employment of the most disadvantaged population was put forward by many hammam managers and key stakeholders. As A.K. and Y.L. (from the Association of Hammam Managers in Marrakech) describe:

"The hammam is a social sector, a very good employment provider and a central element of residential neighborhoods. [ . . . I It is clear that the hammam owner provides an important social function. The "hmahmi" is the small chief of the neighbourhood and a medium provider of employment." (A.K., age: $60 \mathrm{~s}$ )

"The Hammam is known as 'the Silent Doctor'. This need to be highlighted. [... ] Medium to low-income population in Morocco relies heavily on the ham- 
mam as the entrance fee is affordable and varies between 10 to 12 Moroccan Dirhams." (Y.L., age: $50 \mathrm{~s}$ )

Although hammams offer clear societal benefits in Morocco, they do, however, contribute to putting a strain on scarce resources in their current mode of operation, increasing the vulnerability of the local population to natural hazards [53]. As a matter of fact, water resources (from wells, rivers, lakes etc.) are currently under heavy stress in North Africa, due to frequent droughts induced by climate change and rapid urbanisation [34].

During the water forum, a representative from the hydraulic basin of Benslimane (A.Z.) highlighted that parts of Morocco are experiencing a parallel decrease in water resources (due to reduced rainfalls and overexploitation of groundwater) and increase in water demand (due to economic and social development), with negative environmental consequences. In the hydraulic basin of Benslimane (which serves 9 million people and covers an area of approximately $20,000 \mathrm{Km}^{2}$ in which $68 \%$ of the economic activity of Morocco is concentrated), available water resources amount to as little as $106 \mathrm{~m}^{3}$ per person per year (i.e., well below the threshold of water scarcity). Current estimates set the saturation of drinking water resources in Casablanca between 2025 and 2027. However, demand for industrial and tourism drinking water - this includes hammams' water quotain the area of the basin is projected to raise by 1.7 times by 2050 (A.Z.).

Connected issues include water wastage in hammams due to the careless behavioural practices of users and staff, coupled with the use of non-renewable energy resources for heating the water, and the use of water from private hammam wells (to keep water costs low), which is high in limescale and reduces the energy efficiency of hammam boilers and might affect the health of the hammam users if not monitored. Furthermore, the drainage of the hammam used hot water, which reaches the sewage system at about 35 degrees Celsius, i.e., above the regulatory limit for sewer systems, can lead to the degradation of the sewage infrastructure, which in turn can cause further environmental degradation.

Arguably, identifying ways to make hammams become more resource-efficient will have dual benefits to both the environment and society.

In the project's virtual water forum discussions, one owner of several hammams (M.K.) noted that the average consumption of a hammam per day is roughly 20 cubic metres of hot water and consequently around one tonne of wood per day. If multiplied by the estimated number of 12,000 hammams in Morocco (which is likely to be below the real number, as no official statistics of hammam numbers are available to date), this number returns a total national estimate of 4 million tonnes of wood each year that is burned in the hammams' furnaces, with a total carbon footprint of $28,000,000 \mathrm{~kg}$ of $\mathrm{CO}_{2}$, assuming that 1 tonne of wood equals $700 \mathrm{~kg}$ of $\mathrm{CO}_{2}$ (M.K.). Despite these numbers, it was pointed out by the head of the association of hammam managers of Marrakech, Y.L., that "a previous study has showed that people use 3 to 4 times more water at home for washing themselves than in the hammam." with A.K. (another member of the association) reporting that the percentage of homes with private bathrooms in Morocco has increased from 19\% to 73\% between 2004 and 2014. A more nuanced consideration of relationships between the use of wood energy in hammams and the ongoing deforestation of Morocco was, then, advocated by another hammam owner, who argued:

"M.K. mentioned $1500 \mathrm{~kg}$ of wood used per day in his hammam [K. in Marrakech]. I think we should not victimise the hammams about their use of wood. As trees in the forest are cut for the wood industry and not for the hammams. The hammams use only the tree roots and leftovers from trees that have been cut by others. We cannot continue to say that the hammams are eating up the Moroccan forests. This is not true, the hammam uses what it can use!" (J.J., age: $40 \mathrm{~s}$ )

It is clear from the arguments above that the conclusions reached by engineers in their calculations of wood and water consumption in hammam furnaces and their resulting damaging impact on the environment are contested by hammam managers, who see that the hammams are using leftovers of trees who are cut by another sector and that the 
consumption of the shared resource of hot water in the hammam is far below that of the individual use of bathrooms in private houses and hotel rooms. The importance of considering place-based factors in decision-making, overcoming the assumption of the spatially blind diffusion and viability of transition technologies, emerged clearly from these discussions.

Another element that was discussed is the influence of behavioural aspects on resources' consumption. K.K. (hammam owner, age: $80 \mathrm{~s}$ ) argued that the perceived unlimited availability of resources in Moroccan cities and changing lifestyles means that the practices of urban hammam users are becoming increasingly unsustainable, with people wasting large amounts of water and dwelling in the hammams for too long.

Historical data on human-caused greenhouse gas (GHG) emissions [58] indicate that the total amount of $\mathrm{CO}_{2}$ produced in Morocco is steadily increasing: in 1998 it was $26 \mathrm{MtCO}_{2}$, and in 2008 it was $46 \mathrm{MtCO}_{2}$, reaching a peak of $65 \mathrm{MtCO}_{2}$ in 2018.

Previous research has offered useful insights on this trend [59], drawing a link between raising levels of energy consumption in Morocco, environmental degradation due the country's large use of fossil fuels and social development (indicated by higher life expectancy, per capita income, and education levels, among other elements). In line with [11], the authors pointed out the need to boost economic development, which would then drive an increase in levels of environmental awareness in the local population.

This suggests that a better understanding of links between the use of ecological transition technologies, society and space is needed to inform environmental design and planning.

N.C. (researcher, age: $30 \mathrm{~s}$ ) argued that, as urbanisation in Morocco proceeds at highspeed, local authorities are becoming concerned about environmental nuisance (e.g., water, air and plastic pollution) from informal hammams located in informal settlements (whose vulnerability to climate change has been intensified by the pandemic [53]), especially in peri-urban areas. In a study conducted in Dar-Bouazza, N.C. found that $50 \%$ of these informal hammams reject their wastewater directly into nature or into undersized septic tanks, with each hammam consuming 10-100 tons of water and 1 ton of wood per day to serve a daily clientele varying between 45 and 400 people.

N.C. is part of a group of local researchers (together with B.E.A., F.B., M.Z. and F.A.), whose proposal is to tackle these problems by working with closed cycles of resources in growing city regions, pushing for Water-Energy coupling in peri-urban and rural areas [16]. The team tested this approach by working at three different scales: it examined the problem at a regional level (macro-scale), it produced scenarios at the meso-scale and carried out a set of pilot projects locally (micro-scale), (F.A).

At a micro-scale level, the specific technical solutions proposed by this group for reducing hammams' environmental impact are varied and include (i) reusing hammams' wastewater for urban agriculture and green infrastructure after adequate treatment, contributing to restore underground water reserves, (ii) recovering the heat stored in the hammam wastewater using a heat exchanger to prevent damaging ecosystems while saving energy resources, which can feed forward the industry, (iii) installing solar collectors for pre-heating rainwater, (iv) insulating the walls of the hot room as well as hot pipes and the boiler to achieve greater energy savings and enhance indoor comfort, (v) raising awareness among all stakeholders, women in particular, within pedagogical engagement and demonstration projects such as urban agriculture initiatives, besides considering the use of solar collectors to run rainwater pumps and/or power batteries for lighting hammams' spaces.

The data presented by M.Z. (researcher, age: 30 s) about the hammams in Dar-Bouazza (located in the outskirts of Casablanca) suggest that carrying out all the listed improvements within the local municipality, implementing energy and water recovery solutions while reducing water consumption for its $\sim 20$ hammams, would cut $\mathrm{CO}_{2}$ emissions by twothirds, bringing it down to $6.1 \mathrm{t}$ from $18.8 \mathrm{t}$ per day. While F.B. (senior academic, $50 \mathrm{~s}$ ) noted that additional improvements may be done, such as using solar collectors to pump rainwater and power batteries for lighting the hammams, it was highlighted by B.E.A. (senior academic, age: $50 \mathrm{~s}$ ) that the appropriate combination of hammam retrofitting 
solutions should be developed case by case, considering the variety of hammams' size, typology and location. This suggests the need for a strategic framework for selecting watersaving measures in hammam rehabilitation projects while targeting an efficient energy transition. This should overcome technology-centric and system-specific solutions and offer experts a whole-life perspective on water saving design and management strategies as in [60].

In all cases, holistically addressing water and energy as a binomial was pointed out by all the researchers and other participants as key to enable the Eco-hammam vision. In other words, an Eco-hammam differentiates itself from a traditional one by its ability to become a nexus for sustainability innovation, networking services for substantially reducing the direct and indirect negative impacts of its operation. As F.B. explains:

"We are not interested so much in the boiler part because most of the energy savings that can be realised [via the water] do not come from the boiler, and as there are many studies [on energy efficient boilers]. We are mainly interested in the energy that we can recover, i.e., at the level of [preheating water using] the solar collectors and via the recovery of the energy and heat contained in the [used hot] water [before it drains away in the sewage]." (F.B., age: $50 \mathrm{~s}$ )

Since hammam clients often use a large amount of hot water and therefore the furnace needs a large amount of wood for water heating, this integrated approach would enable a multisectoral, and therefore more holistic, reduction of costs, with clear economic and social health gains (N.C.). Nevertheless, F.B. argued that, if investing in the retrofitting of individual hammams will certainly pay back the hammam owner in the medium and long term, to obtain relevant environmental results, it is necessary to work holistically and simultaneously with technical and behavioural aspects within all the hammams within every local municipality, through coordinated actions.

\subsection{Energy Transition Technologies}

A set of suitable engagement case study hammams were identified in each of Rabat, Casablanca and Marrakech during the first two Eco-hammam virtual forums and were used as conversational prompts during the third one to discuss pros and cons of implementing different energy transition technologies. Managers of the following hammams have contributed to all the forums, presenting their experience.

- Hammam R. (Rabat). This hammam was built in the 1950s, owned by the Ministry of Religious Endowments and Islamic Affairs and leased to a woman (an official partner of the Eco-hammam project) who has managed the hammam for more than 30 years. She has taken an active part in the COP 22 in Marrakech and, to date, has implemented a range of different energy transition technologies [61]. Firstly, she installed the early version of 'hammam improved furnace', developed by the AMEE in the 1990s in collaboration with GTZ. This was then followed by a hybrid biomass boiler and solar thermal energy-efficient system, installed through the partnership of GERES (French NGO) and ENSEN (Moroccan NGO) as part of a funded project by the French Development Agency [62]. Subsequently, she replaced this with a locally produced biomass boiler, abandoning the solar thermal system due to technical problems. Other interventions in this hammam include the retrofitting of the vernacular daylighting system, which removed the necessity to use costly electric lighting during the day.

- Hammam J. (Casablanca). This hammam is owned by an active participant to the Eco-hammam project online forum events who implemented a biomass-fuelled waterheating system.

- Hammams K. (Marrakech). These four hammams are relatively new and built in a low-income residential neighbourhood. They belong to an engineer, who pioneered the energy transition using hybrid solar thermal and biomass high efficiency furnace. He has collaborated with different national and international initiatives to install hybrid energy production systems, experimenting in each hammam with a different 
solar thermal technology. His experience and results were presented at the COP 22 in Marrakech and he is an official partner for the Eco-hammam project.

- Private residential hammam (Marrakech). This is embedded in a private house and is the result of a successful design-research experiment on a solar heating system for residential hammams [63], led by a researcher in the Ecole Nationale d'Architecture de Marrakech (ENAM).

Following the presentation of the case studies, strengths and weaknesses of the different approaches and technologies adopted were compared and contrasted by means of a SWOT (Strengths, Weaknesses, Opportunities, and Threats) analysis conducted by the hammam managers (Table 1). The alternative options discussed in the forum present the advantage of enabling the switch from the use of fossil fuels to biomass- and solar-powered water heating systems without relying excessively on Morocco's energy system capacity (the reported increase in the use of electricity in three of the hammams owned by M.K. has been of around $20 \mathrm{MWh}$ per year). Nevertheless, Morocco has substantially increased electricity access rates in the past decade and is committed to continue strengthening its energy supply security through the use of renewable energy resources [19].

Table 1. SWOT analysis results for four types of hammam furnaces.

\begin{tabular}{|c|c|c|c|}
\hline Traditional Boiler & $\begin{array}{c}\text { Improved Boiler } \\
\text { by AMEE }\end{array}$ & Biomass Boiler & Solar Heating \\
\hline \multicolumn{4}{|c|}{ Strengths } \\
\hline $\begin{array}{c}\text { Based on local } \\
\text { vernacular know-how. } \\
\text { Affordable. }\end{array}$ & $\begin{array}{c}\text { Reliable solution } \\
\text { producing plenty of } \\
\text { hot water. }\end{array}$ & $\begin{array}{c}\text { Energy / fuel } \\
\text { consumption reduced } \\
\text { by up to } 70 \% .\end{array}$ & $\begin{array}{l}\text { Partial elimination of } \\
\text { fuel costs and no } \\
\text { hidden expenses. }\end{array}$ \\
\hline \multirow[t]{8}{*}{ Uses the Hypocaust } & $\begin{array}{l}\text { Wood saving/less } \\
\text { energy waste. }\end{array}$ & $\begin{array}{l}\text { Low cost of } \\
\text { biomass. }\end{array}$ & Safe working system. \\
\hline & $\begin{array}{c}\text { Limited smoke } \\
\text { emissions, low health } \\
\text { hazard. }\end{array}$ & $\begin{array}{l}\text { Temperature } \\
\text { control. }\end{array}$ & $\begin{array}{c}\text { Significant cut of } \mathrm{CO}_{2} \\
\text { emissions. }\end{array}$ \\
\hline & $\begin{array}{l}\text { Locally produced } \\
\text { with availability on } \\
\text { the market }\end{array}$ & $\begin{array}{c}\text { Limited smoke } \\
\text { emissions, low health } \\
\text { hazard. }\end{array}$ & $\begin{array}{l}\text { Little upkeep and } \\
\text { maintenance. }\end{array}$ \\
\hline & & $\begin{array}{l}\text { Automation } \\
\text { capacity. }\end{array}$ & $\begin{array}{c}\text { Positive image } \\
\text { (shows a certain sense } \\
\text { of responsibility). }\end{array}$ \\
\hline & & Easy Installation. & $\begin{array}{c}\text { Energy and economic } \\
\text { independence. }\end{array}$ \\
\hline & & $\begin{array}{l}\text { Adapts capacity } \\
\text { according to } \\
\text { hammam } \\
\text { attendance. }\end{array}$ & $\begin{array}{l}\text { Sufficient on its own } \\
\text { for heating water } \\
\text { during the summer } \\
\text { season. }\end{array}$ \\
\hline & & $\begin{array}{l}\text { Locally produced } \\
\text { with availability on } \\
\text { the market. }\end{array}$ & \\
\hline & & $\begin{array}{c}\text { High return on } \\
\text { investment (not more } \\
\text { than } 6 \text { months). }\end{array}$ & \\
\hline
\end{tabular}


Table 1. Cont.

\begin{tabular}{|c|c|c|c|}
\hline Traditional Boiler & $\begin{array}{l}\text { Improved Boiler } \\
\text { by AMEE }\end{array}$ & Biomass Boiler & Solar Heating \\
\hline \multicolumn{4}{|c|}{ Weaknesses } \\
\hline $\begin{array}{l}\text { High consumption of } \\
\text { wood. }\end{array}$ & $\begin{array}{l}\text { Does not use the } \\
\text { hypocaust i.e., } \\
\text { "Chabka". }\end{array}$ & $\begin{array}{l}\text { Unstable and } \\
\text { unaffordable market } \\
\text { costs. }\end{array}$ & $\begin{array}{l}\text { Needs close } \\
\text { monitoring. }\end{array}$ \\
\hline $\begin{array}{c}\text { Emissions of } \mathrm{CO}_{2} \\
\text { smoke and ash waste. }\end{array}$ & $\begin{array}{c}\text { Expensive } \\
\text { installation costs. }\end{array}$ & $\begin{array}{l}\text { Needs Furnace staff } \\
\text { literacy and training. }\end{array}$ & $\begin{array}{c}\text { Expensive } \\
\text { installation costs. }\end{array}$ \\
\hline $\begin{array}{l}\text { Temperature rise and } \\
\text { transformation of } \\
\text { water into steam } \\
\text { impacting costumers' } \\
\text { experience. }\end{array}$ & $\begin{array}{l}\text { Slow uptake by } \\
\text { hammam managers } \\
\text { unless subsidised. }\end{array}$ & $\begin{array}{l}\text { Biomass distribution } \\
\text { networks need to be } \\
\text { improved and } \\
\text { controlled. }\end{array}$ & $\begin{array}{l}\text { Needs the } \\
\text { combination with a } \\
\text { biomass boiler to } \\
\text { continue heating the } \\
\text { water to } 60 \text { degrees } \mathrm{C} \\
\text { (heats up to } 30^{\circ} \text { in } \\
\text { spring and } 50^{\circ} \text { in } \\
\text { summer). }\end{array}$ \\
\hline $\begin{array}{l}\text { Difficult maintenance } \\
\text { and high cost. }\end{array}$ & $\begin{array}{l}\text { Not widely } \\
\text { Manufactured. }\end{array}$ & $\begin{array}{l}\text { Competition from } \\
\text { foreign distributors of } \\
\text { biomass boilers made } \\
\text { in Europe. }\end{array}$ & $\begin{array}{c}\text { Large area needed to } \\
\text { install the solar } \\
\text { panels. }\end{array}$ \\
\hline $\begin{array}{l}\text { Health hazard linked } \\
\text { to the use of sawdust. }\end{array}$ & & & $\begin{array}{l}\text { Lack of follow-up } \\
\text { from installers. }\end{array}$ \\
\hline \multicolumn{4}{|l|}{$\begin{array}{l}\text { High fire risk and } \\
\text { accidents. }\end{array}$} \\
\hline \multicolumn{4}{|c|}{ Opportunities } \\
\hline \multirow[t]{2}{*}{$\begin{array}{l}\text { Has potential for } \\
\text { improvement and } \\
\text { reducing risks. }\end{array}$} & $\begin{array}{l}\text { Large-scale } \\
\text { manufacturing for } \\
\text { improving } \\
\text { affordability. }\end{array}$ & $\begin{array}{l}\text { Uptake increased by } \\
\text { small Hammams- } \\
\text { it consumes only the } \\
\text { necessary quantity of } \\
\text { granulate. }\end{array}$ & $\begin{array}{c}\text { Uptake can increase } \\
\text { when state subsidies } \\
\text { and/or bank loans at } \\
0 \% \text { interest are made } \\
\text { available. }\end{array}$ \\
\hline & & $\begin{array}{l}\text { Awareness-building } \\
\text { (e.g., via } \\
\text { demonstration of } \\
\text { existing facilities and } \\
\text { availability data } \\
\text { about returns on } \\
\text { investments. }\end{array}$ & Creation of new jobs. \\
\hline \multicolumn{4}{|c|}{ Threats } \\
\hline \multirow[t]{5}{*}{$\begin{array}{l}\text { Disappearance of } \\
\text { traditional know how. }\end{array}$} & Lack of funding. & $\begin{array}{l}\text { Low cultural } \\
\text { acceptance. }\end{array}$ & $\begin{array}{l}\text { High investment } \\
\text { costs. }\end{array}$ \\
\hline & & $\begin{array}{l}\text { Fear of technical } \\
\text { breakdowns of motor } \\
\text { pumps. }\end{array}$ & $\begin{array}{l}\text { Seasonal risk of being } \\
\text { left with cold water } \\
\text { only during the day. }\end{array}$ \\
\hline & & $\begin{array}{l}\text { Lack of technical } \\
\text { Follow up. }\end{array}$ & $\begin{array}{l}\text { Lack of technical } \\
\text { Follow up. }\end{array}$ \\
\hline & & $\begin{array}{l}\text { Needs Furnace staff } \\
\text { literacy and training. }\end{array}$ & $\begin{array}{l}\text { Technical risks of the } \\
\text { installation and } \\
\text { potential loss of } \\
\text { clients. }\end{array}$ \\
\hline & & & $\begin{array}{l}\text { Overheating in } \\
\text { summer. }\end{array}$ \\
\hline
\end{tabular}


In addition to recording the hammam managers' experience of these six public hammams with different levels of energy transition, and of one private residential hammam, data were collected from other actors contributing to the discussion sessions. These include the President of the National Federation of hammam managers in Morocco (R.O.), the president of the Association of hammam managers in Marrakech (Y.L.) and other hammam managers from Fez and other regions who were able to access and attend to virtual forums.

Identifying owners and managers' priorities and barriers was considered crucial during the forum on water, when a member of a local NGO (A.B.) pointed out that, although hammam owners could play a key role in enabling hammams' ecological transition, they tend to resist it.

When asked about their preferred energy transition technology, many managers indicated boilers powered by biomass from local agricultural product waste as the most viable option for Moroccan hammams. Although K.K. described her experience with the installation of a solar thermal system for pre-heating the hammam water as positive overall, she argued that subsidies and wood savings played a role in overcoming the barrier of the higher initial investment costs. The installation of solar thermal panels was deemed by many as less convenient than that of biomass boilers also due to the misalignment of energy production peaks with the seasonal fluctuations of hammam clients' numbers.

"So how do we change the system to reduce deforestation and $\mathrm{CO}_{2}$ emissions induced by the operation of hammam furnaces? [ . . ] biomass as renewable energy is widely available in Morocco in the form of products from olive oil and argan oil presses. Olive stones and argan nutshells are now being used as biomass in more energy efficient furnaces and are three to four times cheaper than wood." (M.K., age: $30 \mathrm{~s}$ )

"The weakness of solar thermal is that it works best in the summer season which is not the season when we have the largest number of hammam clients. The high investment costs also make the biomass boilers as more relevant." (J.J., age: $40 \mathrm{~s}$ )

"As for the biomass, I hope we can help small enterprises producing biomass. There are also locally produced biomass boilers which are very useful. We need to train builders for the construction of hypocaust. We need to train craftsmen who can build cheap and affordable locally produced biomass boiler technologies. [ ... ] I found a locally produced and affordable biomass boiler which provides sufficient capacity for an average number of 100 clients per day. With this, I do not exceed $180 \mathrm{~kg}$ per day of argan nut shells, which is absolutely extraordinary! So I insist on the use of biomass and we need to find solutions for increasing the adoption of biomass boilers. However, we need subsidies to help hammam managers adopt this technology" (K.K., age: 80 s)

Tensions between traditional and contemporary systems have been apparent in the comments made by the hammam managers. For example, the use of the hypocaust is considered as more economical in the long term than the hot water underfloor serpentine system, which is more expensive to install, relies on imported technologies and has a lifespan of ten years (K.K.). However, participants highlighted the disappearance of an ancestral know-how of craftsmen with expertise in hypocaust construction and maintenance.

Such a system, which has sustained itself in Morocco since the Roman civilization, is perceived as more environmentally friendly and cost effective long-term in terms of the local construction materials it uses and thus better than the highly carbon hungry materials such as those employed serpentine technology (K.K.).

Hammam managers fear furnace breakdowns, which can lead to the immediate loss of clientele and earnings, and the lack of timely maintenance support in case of breakdowns continues to be an important source of anxiety (J.J. and K.K.). Another barrier is the difficulty to employ furnace staff that are able to work with the new technologies and which will require expertise that need a higher salary. 
Therefore, when evaluating viability of a new technology, hammam managers look at the local availability of skilled workers, cheap to employ, with the ability to build, install and maintain it, besides the capacity of locally produced technologies to reliably cover hammams' daily energy needs and the availability of financing schemes that can help with the initial investment in energy transition technology.

The economic aspect was central to the discourses of hammam owners and managers, and researchers seemed aware of the issue as B.E.A. pointed out the need for compact innovative systems, passive, to be used cheaply, to encourage owners to adhere to water treatment and reuse systems, which are largely going unconsidered at the moment.

Although evidence of cost investment recovery was provided by those who carried out the retrofitting of their furnaces - and varies between 2 to 3 years for biomass boilers and 4 to 5 years for solar thermal (M.K.) - hammam managers continue to insist that a governmental subsidy system would be their preferred option, particularly in light of the current impact of COVID-19 leading to the closure of hammams for more than a year. A.K. marked that the hammam "is a fragile sector, not well organised, suffers from high costs associated with maintenance and refurbishment and from the lack of subsidies." (A.K., $60 \mathrm{~s}$ ). However, subsidising interventions in a sector that is not fully understood in all its complexity presents several challenges, and past schemes led to either an inefficient use of resources or to an ill-informed financial planning:

"There are no governmental subsidies that are available at the moment. For our energy transition projects, we had a loan from ENSEN at $0 \%$ interest. However, ENSEN was not able to retrofit 40 hammams with solar thermal technology as initially planned, they only managed to do it for five or six hammams only." (M.K., age: $30 \mathrm{~s}$ )

After centuries of operation, the hammam sector is clearly in danger of being made obsolete in its traditional form and it is now struggling to maintain the right balance between environmental sustainability and social justice to remain affordable. Although it has been described as an important social sector in Morocco, its fragility has been highlighted by many different stakeholders, especially by hammam managers who perceive it as an indispensable service to those who are most deprived and vulnerable.

Threats associated with the proliferation of new spas and Turkish baths, which are oriented to a wealthier clientele and high fee-paying tourists, have been clearly articulated, indicating the necessity to "regulate" their numbers in relation to the more socially oriented Moroccan hammam facilities with adequate policies.

"There is currently a fierce competition for the Moroccan hammam and public showers sector with the proliferation of spas, Turkish baths, apartment hammams, who exercise other illegal functions under the names of massages, then you have the hotel spas. [ ... ] Hammams have been asked to pay taxes (TVA), however, the Federation of the Hammam Managers has been able to knock at the door of the Minister and ask for this to be cancelled. The tax is not currently applied for the hammams, but things can change in the future." (A.K., age: $60 \mathrm{~s}$ )

"The planning regulations for neighbourhood public services need to be revised with the aim to avoid the proliferation of many hammams in the same neighbourhood. [ ... ] The regulation states one hammam for every 5 hectares and not in relation to the population density. This is the way it is stated in the national table for the provision of urban facilities. We are planning to have a meeting with the Ministry of Housing to raise this issue and have the involvement of the National Federation of Hammam Managers to contribute to this law." (A.K., age: $60 \mathrm{~s}$ )

The deliberative discussions supported social learning and the identification of realistic and feasible energy transition scenarios, considerate of how energy production and consumption links to hot water usage, lighting, indoor comfort, health and safety, etc.

As a by-product, the problems and expectations of hammams owners and managers in relation to the adoption of energy transition technologies were identified and mapped. The 
resulting priorities (linked to economic, social-cultural and environmental considerations) and barriers (related to governance and economic issues, or policy-induced) of stakeholders in relation to ecological transition initiatives are summarised in Table 2.

Table 2. Priorities and barriers of hammam owners and managers to the adoption of energy transition technologies.

\begin{tabular}{|c|c|c|c|}
\hline & Environment & Society and Culture & Economy \\
\hline \multirow{3}{*}{ Priorities } & $\begin{array}{l}\text { Implementing water } \\
\text { saving strategies and } \\
\text { raise awareness of } \\
\text { clients to avoid wasting } \\
\text { water. }\end{array}$ & $\begin{array}{l}\text { Improving indoor } \\
\text { conditions in terms of } \\
\text { natural ventilation and } \\
\text { daylighting and } \\
\text { applying health and } \\
\text { safety regulations. }\end{array}$ & $\begin{array}{l}\text { The need for subsidies } \\
\text { or interest-free loans for } \\
\text { energy transition in } \\
\text { hammam furnaces, } \\
\text { allowing reimbursement } \\
\text { based on savings } \\
\text { achieved. }\end{array}$ \\
\hline & $\begin{array}{l}\text { Use of efficient biomass } \\
\text { boilers to protect the } \\
\text { forest and reduce air } \\
\text { pollution. }\end{array}$ & $\begin{array}{l}\text { Maintaining } \\
\text { employment } \\
\text { opportunities in } \\
\text { hammams and ensure } \\
\text { the affordability of the } \\
\text { service. }\end{array}$ & $\begin{array}{l}\text { Protect the economic } \\
\text { viability of the hammam } \\
\text { as a social-oriented } \\
\text { business. }\end{array}$ \\
\hline & $\begin{array}{l}\text { Use of renewable energy } \\
\text { from solar thermal } \\
\text { panels to preheat } \\
\text { hammam water. }\end{array}$ & $\begin{array}{l}\text { Maintain tangible and } \\
\text { intangible heritage of } \\
\text { Moroccan hammams. }\end{array}$ & $\begin{array}{l}\text { Making economies from } \\
\text { combining cheap } \\
\text { water-energy solutions. }\end{array}$ \\
\hline \multirow{5}{*}{ Barriers } & Governance & Policy-Induced & Economic \\
\hline & $\begin{array}{l}\text { Lack of organisation, } \\
\text { initiative, and } \\
\text { engagement of regional } \\
\text { associations of } \\
\text { Hammam mangers. }\end{array}$ & $\begin{array}{l}\text { Lack of policies limiting } \\
\text { the proliferation of } \\
\text { hammams in the same } \\
\text { neighbourhood. }\end{array}$ & $\begin{array}{l}\text { Economic fragility due } \\
\text { to difficult financial } \\
\text { balance following } \\
\text { seasonal attendance } \\
\text { variations and constant } \\
\text { negotiations over new } \\
\text { tax impositions. }\end{array}$ \\
\hline & $\begin{array}{l}\text { Lack of a } \\
\text { government-led plan for } \\
\text { hammams' } \\
\text { rehabilitation and } \\
\text { modernisation. }\end{array}$ & $\begin{array}{l}\text { Lack of training and } \\
\text { capacity building for } \\
\text { running new } \\
\text { technologies of human } \\
\text { resources. }\end{array}$ & $\begin{array}{l}\text { Lack of economic } \\
\text { subsidies for installation } \\
\text { of new technologies. }\end{array}$ \\
\hline & $\begin{array}{l}\text { Lack of communication } \\
\text { and coordination } \\
\text { between different } \\
\text { Ministries linked to the } \\
\text { hammam sector. }\end{array}$ & $\begin{array}{l}\text { Lack of skills for the } \\
\text { local production and } \\
\text { maintenance of clean } \\
\text { technologies and } \\
\text { biomass boilers. }\end{array}$ & $\begin{array}{l}\text { Fear of breakdowns } \\
\text { which would bring loss } \\
\text { of income. }\end{array}$ \\
\hline & $\begin{array}{l}\text { Lack of top-down } \\
\text { coordinated local } \\
\text { planning of ecological } \\
\text { transition measures. }\end{array}$ & $\begin{array}{l}\text { Lack of regulations } \\
\text { controlling the number } \\
\text { of hammams per density } \\
\text { of inhabitants. }\end{array}$ & $\begin{array}{l}\text { Difficulty to pay higher } \\
\text { salaries to employ } \\
\text { difficult-to-find furnace } \\
\text { staff able to work with } \\
\text { the new technologies. }\end{array}$ \\
\hline
\end{tabular}

\section{Discussion and Conclusions}

The hammam sector is where numerous environmental, economic and social sustainability domains intertwin and interlace. It is therefore well placed to contribute to sustainability innovation in Morocco and more broadly in North Africa. Nevertheless, there seems to be a lack of understanding of links between the different domains and sectors that hammams intersect, which represents a challenge for effectively governing their ecological transition.

Through the online forum activities described above, hammam actors in Morocco were given the opportunity to form a network supporting the hammams' ecological transition process. Several problems - but also some potential cross-regional synergies-were identified, which could help to better respond to the current climate and energy challenges. The paper has highlighted how ecological and environmental considerations stand in relation to cultural and social practices associated with Moroccan hammams. 
The results indicate there are contradictory views between the hammam managers and users and the experts' statements. For example, the statistics about deforestation in Morocco and their relationship to the hammam sector were challenged. In the same way, scientific analyses about the water quality in hammam wells and the risks associated with the results were underplayed by the hammam managers who refuse to accept the existence of the problem, let alone act on it. Their reasoning is that the hammam serves the wellbeing of the local population and needs to remain affordable, which requires accessing the free water from the hammam well if this is available.

Nevertheless, it is clear that the narrow focus on environmental sustainability, as it was emphasised during the COP 22 in Marrakech in 2016, can lead to the disappearance of socially and culturally sustainable practices, breaking a whole chain of an informal economy that has thrived for many centuries. The emphasis on locally produced bespoke technologies and the co-production of strategies with stakeholders that have high power in influencing change and yet have little interest in doing so, indicate that the acceleration of ecological practices in the hammam sector requires both bottom-up and top-down approaches that are coordinated and simultaneous to enable the co-production of holistic strategies that can be implemented by key stakeholders in alignment with other actors.

By drawing a clear link between short-sighted practices and problems of deforestation, water scarcity, air quality and environmental depletion, as well as behavioural and socioeconomic factors, this paper illustrates a new vision for Moroccan hammams, i.e., the Eco-hammam. By addressing multiple Sustainable Development Goals (SDGs), the Ecohammam ultimately represents an ideal concept for how this socio-cultural sector can strengthen its resilience and successfully adapt to the new challenges posed by climate change. The Eco-hammam enshrines a commitment to environmental and social goals that is central to culturally sensitive Sustainable Development. It is a primary example of where such divergent agendas meet and need to be reconciled through dialogue.

The paper demonstrates that enabling this vision is not without difficulties. The slow uptake of new and cleaner technologies seems partly due to a poor consideration of barriers and priorities of hammam owners and managers by development agencies and experts and to a poor understanding of the way the hammam industry traditionally operates. Hammam managers seem generally aware of the environmental and economic benefits of adopting energy efficient biomass boilers but continue using wooden-fuelled furnaces due to their inability to afford the initial high investments costs associated with the adoption of greener technologies, and their fear for technical failures of new technologies and a lack of follow up from those providing them and the resulting loss of clients. Overall, hammam managers and owners appear more aware of clean energy systems for hammam furnaces than of water recycling systems, which necessitate more complex interventions in collecting and treating hammam grey water.

As a result, firstly, the pursuit of energy transition in Moroccan hammams requires the development of a multi-level governance approach. This should bring actors at crosssectoral levels to work together to generate financial assistance, within a regulatory framework that supports the implementation and maintenance of the energy transition in hammam furnaces. Secondly, the transformation of energy systems in hammams not only requires technological capacities and capacity building among hammam workers, but to increase adoption numbers it would also benefit from economic incentives, and a strong political will to drive them. However, these will not be effective without parallel efforts to support behavioural change of hammam managers, workers, and users.

Public awareness about water has been recently implemented in the engagement activities organised by the Museum of Water in Marrakech (funded by the Ministry of Religious Endowments and Islamic Affairs). Nevertheless, it is very clear that the water museum could further strengthen its links with the hammam sector and in particular the heritage hammams, which fall under the responsibility of the same Ministry.

Of all the cities in Morocco, Marrakech seems to have the highest concentration of hammams that have adopted energy transition measures. The heritage hammams located 
in the intra-muros area of its world heritage medina, however, have not yet engaged with the process. Nevertheless, there is a concentration of know-how and expertise in Marrakech (academics and researchers, AMEE, NGOs, local hammam managers association, Museum of Water) that could ignite innovative sustainability catalysis projects, supporting the integrated and holistic ecological transition of Moroccan hammams.

Future research efforts will thus address the co-creation and testing of an Eco-hammam toolkit to support the construction of lever projects to carry out joint actions in Marrakech and beyond. The toolkit will be available in different formats that are easily accessible to different groups of stakeholders and should leverage local knowledge of the Food-WaterEnergy nexus, enhancing social practices in relation to nexus threats such as droughts, desertification and air pollution.

Author Contributions: Conceptualization, M.S. and C.P.; methodology, M.S., C.P. and C.T.; software, C.P.; formal analysis, M.S. and C.P.; investigation, M.S., C.P. and C.T.; resources, M.S.; data curation, M.S. and C.P.; writing—original draft preparation, C.P. and M.S.; writing—review and editing, M.S., C.P. and C.T.; visualization, C.P.; supervision, M.S. and C.T.; project administration, M.S. and C.P.; funding acquisition, M.S. and C.T. All authors have read and agreed to the published version of the manuscript.

Funding: This research was funded by UKRI AHRC, AH/T007036/1.

Institutional Review Board Statement: Ethical review and approval were waived for this study because this is not a requirement for online engagement activities.

Informed Consent Statement: Informed consent was obtained from all subjects involved in the study.

Data Availability Statement: The data presented and analysed in this study are available in the form of video recordings in the Eco-hammam project website [https://ecohammam.com/ (accessed on 26 August 2021)] and Youtube channel [https:/ /www.youtube.com/channel/UCGM6 MIdkHrksxDw9Fh3yQpg (accessed on 26 August 2021)].

Acknowledgments: The authors acknowledge all the forum participants and the project partners for their key contributions, in particular ENAM staff for the administrative and technical support in the organisation and delivery of the Eco-hammam virtual forums.

Conflicts of Interest: The authors declare no conflict of interest.

\section{References}

1. Sibley, M.; Jackson, I. The architecture of Islamic public baths of North Africa and the Middle East: An analysis of their internal spatial configurations. Arq Arch. Res. Q. 2012, 16, 155-170. [CrossRef]

2. Sibley, M. Special Issue on Traditional Public Baths-Hammāms in the Mediterranean. Int. J. Archit. Res. ArchNet-IJAR 2008, 2, 10-16.

3. Graiouid, S. Communication and the social production of space: The hammam, the public sphere and Moroccan women. J. North Afr. Stud. 2004, 9, 104-130. [CrossRef]

4. Staats, V. Ritual, Strategy, or Convention: Social Meanings in the Traditional Women's Baths in Morocco. Front. A J. Women Stud. 1994, 14, 1-18. [CrossRef]

5. Sibley, M.; Sibley, M. Hybrid transitions: Combining biomass and solar energy for water heating in public bathhouses'. Energy Procedia 2015, 83, 525-532. [CrossRef]

6. Sibley, M.; Sibley, M. Hybrid green technologies for retrofitting heritage buildings in North African medinas: Combining vernacular and high-tech solutions for an innovative solar powered lighting system for hammam buildings. Energy Procedia 2013, 42, 718-725. [CrossRef]

7. AMEE. The General States of Energy Efficiency in Morocco. Available online: https://www.amee.ma/en/node/126 (accessed on 8 February 2021).

8. GTZ. German Technical Cooperation. Available online: https://www.giz.de/en/html/index.html (accessed on 8 February 2021).

9. AFD. Agence Française de Développement. Available online: https:/ / www.afd.fr/en (accessed on 8 February 2021).

10. Geres. La Solidarité Climatique en Action. Available online: https://www.geres.eu/ (accessed on 8 February 2021).

11. Borowski, P.F. Significance and Directions of Energy Development in African Countries. Energies 2021, 14, 4479. [CrossRef]

12. Dumreicher, H.; Levine, R.S.; Sibley, M. Hammam Rehabilitation Reader; Sonderzahl Verlagsges MbH: Vienna, Austria, 2011.

13. Aries, M.; Aarts, M.P.; van Hoof, J. Daylight and health: A review of the evidence and consequences for the built environment. Light. Res. Technol. 2013, 47, 6-27. [CrossRef] 
14. Wirz-Justice, A.; Skene, D.J.; Münch, M. The relevance of daylight for humans. Biochem. Pharmacol. 2020, 191, 114304. [CrossRef] [PubMed]

15. Sibley, M. Let There Be Light! Investigating Vernacular Daylighting in Moroccan Heritage Hammams for Rehabilitation, Benchmarking and Energy Saving. Sustainability 2018, 10, 3984. [CrossRef]

16. Giseke, U. Urban Agriculture for Growing City Regions: Connecting Urban-Rural Spheres in Casablanca; Taylor and Francis Inc.: Oxfordshire, UK, 2015.

17. Borowski, P.F. Nexus between water, energy, food and climate change as challenges facing the modern global, European and Polish economy. AIMS Geosci. 2020, 6, 397-421. [CrossRef]

18. Trenberth, K.E. Climate change caused by human activities is happening and it already has major consequences. J. Energy Nat. Resour. Law 2018, 36, 463-481. [CrossRef]

19. Choukri, K.; Naddami, A.; Hayani, S. Renewable energy in emergent countries: Lessons from energy transition in Morocco. Energy Sustain. Soc. 2017, 7, 25. [CrossRef]

20. Schinko, T.; Bohm, S.; Komendantova, N.; Jamea, E.M.; Blohm, M. Morocco's sustainable energy transition and the role of financing costs: A participatory electricity system modeling approach. Energy Sustain. Soc. 2019, 9, 1. [CrossRef]

21. Dasgupta, P. The Economics of Biodiversity: The Dasgupta Review; HM Treasury: London, UK, 2021.

22. Kuhn, T.S. The Structure of Scientific Revolutions, 2nd ed.; University of Chicago Press: Chicago, IL, USA, 1970.

23. Guy, S.; Karvonen, A. Using sociotechnical methods: Researching human-technological dynamics in the city. In Understanding Social Research: Thinking Creatively about Method; Mason, J., Dale, A., Eds.; Sage Publications: London, UK, 2011 ; pp. $120-133$.

24. Shove, E. Comfort, Cleanliness and Convenience: The Social Organization of Normality; Bloomsbury Academic: Oxford, UK, 2003.

25. Chappells, H.; Shove, E.A. Debating the future of comfort: Environmental sustainability, energy consumption and the indoor environment. Build. Res. Inf. 2005, 33, 32-40. [CrossRef]

26. Cole, R.J.; Robinson, J.; Brown, Z.; O'Shea, M. Re-contextualizing the notion of comfort. Build. Res. Inf. 2008, 36, 323-336. [CrossRef]

27. Tweed, C.; Dixon, D.; Hinton, E.; Bickerstaff, K. Thermal comfort practices in the home and their impact on energy consumption. Arch. Eng. Des. Manag. 2013, 10, 1-24. [CrossRef]

28. Banham, R. The Architecture of the Well-Tempered Environment; The Architectural Press: London, UK, 1969.

29. Fanger, P.O. Thermal Comfort, Analysis and Applications in Environmental Engineering; McGraw-Hill Book Company: New York, NY, USA, 1970.

30. Smale, R.; Spaargaren, G.; Van Vliet, B. Householders co-managing energy systems: Space for collaboration? Build. Res. Inf. 2018, 47, 585-597. [CrossRef]

31. Ellsworth-Krebs, K.; Reid, L.; Hunter, C.J. Home Comfort and 'Peak Household': Implications for Energy Demand. Housing Theory Soc. 2021, 38, 1-20. [CrossRef]

32. Mathur, V.N.; Price, A.D.F.; Austin, S.; Moobela, C. Defining, identifying and mapping stakeholders in the assessment of urban sustainability. In SUE-MoT Conference 2007, Proceedings of the International Conference on Whole Life Urban Sustainability and Its Assessment, Glasgow, Scotland, UK, 27-29 June 2007; Loughborough University's Institutional Repository: Loughborough, UK, 2007.

33. Meppem, T. The discursive community: Evolving institutional structures for planning sustainability. Ecol. Econ. 2000, 34, 47-61. [CrossRef]

34. Botai, J.; Botai, C.; Ncongwane, K.; Mpandeli, S.; Nhamo, L.; Masinde, M.; Adeola, A.; Mengistu, M.; Tazvinga, H.; Murambadoro, M.; et al. A Review of the Water-Energy-Food Nexus Research in Africa. Sustainability 2021, 13, 1762. [CrossRef]

35. United Nations. The 2030 Agenda for Sustainable Development; United Nations General Assembly: New York, NY, USA, 2015.

36. Mathur, V.N.; Price, A.D.; Austin, S. Conceptualizing stakeholder engagement in the context of sustainability and its assessment. Constr. Manag. Econ. 2008, 26, 601-609. [CrossRef]

37. Komendantova, N. Transferring awareness into action: A meta-analysis of the behavioral drivers of energy transitions in Germany, Austria, Finland, Morocco, Jordan and Iran. Energy Res. Soc. Sci. 2021, 71, 101826. [CrossRef]

38. Sibley, M.; Pezzica, C. ECO-HAMMAM—Share the Resources, Save the Planet! Available online: https://ecohammam.com/ (accessed on 9 February 2021).

39. ODA. Guidance Note on How to Do Stakeholder Analysis of Aid Projects and Programmes; Overseas Development Administration: Richmond, UK, 1995.

40. English Nature. An Introduction to Deliberative Methods of Stakeholder and Public Participation-ENRR474; English Nature: Devon, UK, 2002.

41. Ananda, J.; Herath, G. Incorporating stakeholder values into regional forest planning: A value function approach. Ecol. Econ. 2003, 45, 75-90. [CrossRef]

42. Bryson, J.M. What to do when stakeholders matter: Stakeholder Identificatixon and analysis techniques. Public Manag. Rev. 2004, 6, 21-53. [CrossRef]

43. Rothwell, E.; Anderson, R.; Botkin, J.R. Deliberative Discussion Focus Groups. Qual. Heal. Res. 2015, 26, 734-740. [CrossRef] [PubMed]

44. Morgan, D.L. Focus Groups as Qualitative Research, 2nd ed.; SAGE Publications: Thousand Oaks, CA, USA, 1997.

45. Morgan, D.L.; Krueger, R.A. When to Use Focus Groups and Why. In Successful Focus Groups: Advancing the State of the Art; SAGE Publications, Inc.: Thousand Oaks, CA, USA, 2014; pp. 3-19. 
46. Gibbs, A. Focus groups and group interviews. In Research Methods and Methodologies in Education; Arthus, J., Waring, M., Coe, R., Hedges, L.V., Eds.; SAGE: Thousand Oaks, CA, USA, 2012.

47. Burchardt, T. Deliberative research as a tool to make value judgements. Qual. Res. 2013, 14, 353-370. [CrossRef]

48. Onwuegbuzie, A.J.; Dickinson, W.B.; Leech, N.L.; Zoran, A.G. A Qualitative Framework for Collecting and Analyzing Data in Focus Group Research. Int. J. Qual. Methods 2009, 8, 1-21. [CrossRef]

49. Glaser, B.G.; Strauss, A.L. Discovery of Grounded Theory: Strategies for Qualitative Research-1s; Routledge: Oxfordshire, UK, 2000.

50. Borowski, P.F. New Technologies and Innovative Solutions in the Development Strategies of Energy Enterprises. HighTech Innov. J. 2020, 1, 39-58. [CrossRef]

51. ENAM. Al Mi'mâr I Facebook. Available online: https://www.facebook.com/ENAMarrakech2020/ (accessed on 7 March 2021).

52. Brugha, R.; Varvasovszky, Z. Stakeholder analysis: A review. Health Policy Plan. 2000, 15, 239-246. [CrossRef]

53. UNDP. The Sustainable Development Goals Report 2020; UNDP: New York, NY, USA, 2020.

54. Chapman, A.; Tsuji, T. Impacts of COVID-19 on a Transitioning Energy System, Society, and International Cooperation. Sustainability 2020, 12, 8232. [CrossRef]

55. United Nations. Climate Change and COVID-19: UN Urges Nations to 'Recover Better' I United Nations; United Nations: New York, NY, USA, 2020.

56. Heger, M.; Siegart, L. Going Green after COVID-19 Will Help MENA Economies Recover Better. World Bank Blogs. 2020. Available online: https://blogs.worldbank.org/arabvoices/going-green-after-covid-19-will-help-mena-economies-recoverbetter (accessed on 6 May 2021).

57. Rosenbloom, D.; Markard, J. A COVID-19 recovery for climate. Science 2020, 368, 447. [CrossRef] [PubMed]

58. CAIT: Climate Watch, "Morocco Historical GHG Emissions", Global Historical Emissions. 2021. Available online: https: / / www.climatewatchdata.org/ghg-emissions?end_year=2018®ions=MAR\&start_year=2006 (accessed on 26 August 2021).

59. Haq, I.U.; Zhu, S.; Shafiq, M. Empirical investigation of environmental Kuznets curve for carbon emission in Morocco. Ecol. Indic. 2016, 67, 491-496. [CrossRef]

60. Wu, Z.; Wu, Z.; Li, H.; Zhang, X.; Jiang, M. Developing a strategic framework for adopting water-saving measures in construction projects. Environ. Geochem. Heal. 2019, 42, 955-968. [CrossRef] [PubMed]

61. Bielawski, P.S.; Kaplan, N.S.; Preiss, B.C.; Sousa, A.J.; Vernon, R.J. Developing a Sustainability Plan for Hammams in Morocco; Report; Worcester Polytechnic Institute: Worcester, MA, USA, 2020.

62. Geres. Sustainable Hamams in Morocco: An Essential Service Facing an Environmental Challenge-Geres. Available online: https:/ / www.geres.eu/en/our-actions/our-projects/sustainable-hamams/ (accessed on 18 May 2021).

63. Sobhy, I.; Brakez, A.; Benhamou, B. Energy performance and economic study of a solar floor heating system for a Hammam. Energy Build. 2017, 141, 247-261. [CrossRef] 